\title{
AN ASSESSMENT OF THE LEVEL OF EMOTIONAL INTELLIGENCE ATTRIBUTES OF UNDERGRADUATE BUILT ENVIRONMENT STUDENTS IN DEVELOPING COUNTRIES
}

\begin{abstract}
Built environment students graduate from school possessing good technical skills but lack the rudiments of management and leadership skill. Other challenges faced by students include interpersonal skills, emotional skills, self-awareness and impulse control among others. This research therefore conducts a case study assessing the emotional intelligence (EI) attributes of built environment students. EI questionnaires (EQ-i) were distributed to fourth year undergraduate students studying construction related courses at Kwame Nkrumah University of Science and Technology (KNUST), Kumasi in Ghana. A total of 182 questionnaires were completed and retrieved from the fourth-year students. Analytical tools included descriptive statistics, mean score ranking, regression and correlation. Construction Technology Management (CTM) students had the highest EI value followed by Civil Engineering (CE) students, Quantity Surveying and Construction Economics (QSCE) students and lastly Architecture students. There was no significant difference in the overall EQ-i scores of the fourth-year students. Furthermore, there is insignificant correlation between the built environment programmes and EI level of the students. The results illustrate that the emotional intelligence level of the students is not statistically dependent on the programmes undertaken by the students. From regression analysis, age is a significant predictor of emotional intelligence. This study presents an assessment methodology of the EI levels of built environment students in developing countries and adds to the body of knowledge. The work concludes with direction for future research.
\end{abstract}

\section{KEYWORDS}

Emotional intelligence, EQ-i, built environment, construction, students 


\section{INTRODUCTION}

Many university students still grapple with challenges in their education. These include acquiring interpersonal skills, emotional skills, self-awareness and impulse control among others (Sandy et al., 2012). Even academically bright students face hindrances in the workplace (post-graduation) if certain emotional skills are lacking (Tabish and Jha, 2012). To further exacerbate matters, Parker et al., (2005) revealed that students nowadays are under high stress levels. Their capability to manage this stress in a dynamic and changing environment while preparing to transit to the working environment serves as another significant challenge (Schutte and Malouff, 2002; Crossman, 2007). Past research indicates that built environment students graduate from university possessing good technical skills but lack rudimentary management and leadership skills (Mo and Dainty, 2007). A survey on the views of employers regarding newly qualified engineers indicated that the majority of graduates lacked skills like those of communication and project management (Jagger and Connor, 1998). Research conducted by Chinowsky and Brown (2004) illustrated that civil engineers lagged behind in their emotional intelligence (EI) level when compared to their colleagues in the liberal arts. Students who do not possess the required EI will have challenges with communication, problem solving, leadership and creativity (Mo and Dainty, 2007).

For the past few years, there have been concerted calls for the construction industry to focus on creating a work environment that enables teamwork and cooperation. Such has been facilitated by the use of advanced (and disruptive) digital technological development such as building information modelling (BIM) that allows practitioners to work together in a virtual project environment (c.f. Pärn and Edwards, 2017; Pärn et al., 2018). This adoption has been engendered as part of a concerted effort to progress towards fully 
automating the sector (Edwards and Love, 2016; Edwards et al., 2016). Ironically, the move to create greater team working via technology has inadvertently created distance and barriers between members of the project management team (PMT). To readdress the imbalance created by technology will require greater levels of EI within members of the PMT who will use such skills to ensure project success in terms of cost, time and quality. In recognition of this need, construction companies (at all levels and size) are nowadays asking for employees to possess soft or non-technical skills such as trustworthiness and teamwork (Kemper, 1999). In support of this need, the Accreditation Board for Engineering and Technology (ABET) set criteria for engineering graduates as of 2020 that they should possess more leadership and analytical skills, creativity, ingenuity and professionalism (ABET, 2005). Theoretically and empirically, EI in students in other parts of the world has been well documented by past researchers such as Debarard et al. (2004); Cross (2007); Das (2011); Andi (2012); Iruloh and Ukaegbu (2015) and Zembylas (2017). For a developing country such as Ghana that embraces basic and free education, it is equally important to identify EI in Ghanaian built environment undergraduate students. Such will enable the country's construction sector to remain vibrant and maintain a readily available supply of highly skilled construction professionals.

Given the substantial evidence that EI is useful and positively impacts students' success (Parker et al., 2004; Abdullah et al., 2004), this research therefore aimed at conducting a case study into the EI of built environment students. The specific objectives were to assess the EI of students pursuing different built environment programmes; to identify the relationship between the different built environment programmes and EI; to analyse students' mean scores on total EQ-i and 5 composite scales; and to test the relationship between age and EI of built environment students. The case study's findings are useful in 
assessing the EI level of built environment students and gauges their employability and readiness to face the working environment when they graduate from school. This will lead to better work performance, enhanced team work, and leadership skills which are crucial within the increasingly digital workplace. This study is also beneficial to academia per se as it adds to an existing body of knowledge but will be more specifically useful to construction schools in other developing countries who may face similar challenges.

\section{EMOTIONAL INTELLIGENCE (EI)}

The origin of EI can be linked to Thorndike (1920) who coined the 'social intelligence' concept to explain the capability of people to manage and understand colleagues and to act in acceptable ways when dealing with others. The work of Gardner (1983) has also been influential especially in relation to the concepts of interpersonal and intrapersonal intelligence (Mo and Dainty, 2007). However, the seminal research undertaken by Mayer and Salovey (1990) brought EI research into being a distinct academic discipline and linked it to attributes such as understanding of one's emotions and using it to guide one's actions and thoughts. Since the publication of this seminal research work, academic interest is EI research has spiked significantly - amongst this growth of academic endeavour, the work of Goleman (1995) has perhaps been the most notable. Goleman (ibid) explained EI as possessing skills such as self-motivation, enduring in spite of frustrations and controlling one's mood. In the process of developing a theoretical model, Mayer and Salovey (2004) described EI more of an intellectual ability instead of a competency. This implies that intelligence is required to recognize emotional reactions. EI abilities are useful for people to regulate and recognize their emotions, have self-control, solve conflicts and develop leadership skills (Elias, 2004). According to Zhou and George (2003), managers who have high EI have the capability to identify problems and recognize 
opportunities. Managers having high EI boost the performance of their subordinates and help them become more resilient, creative and confident (Fredrickson, 2003). Managers possessing high EI produce altruistic behaviours and great work output (Carmeli, 2003), they nurture frequent encouraging interactions among employees leading to effective cooperation (Barsade, 2002). Workers with high EI are also noted for excelling in their work output thereby leading to improved performance and job satisfaction (Sy et al., 2005).

EI is fundamentally important for students and has been linked to academic success (Petrides et al., 2004; Schutte et al., 1998). For example, a common thread amongst many mission statements produced by higher education institutions stress both cognitive and non-cognitive maturity of students and their personal growth for life after graduation (Feldmann et al., 2011). An advantage of attending a tertiary institution is the development of social and cognitive skills (Seal et al., 2010; Al-Rabadi, 2012). Intellectual ability and content mastery comprise cognitive skills development (Al-Rabadi, 2012). Positive outcomes of higher education have also been identified as interpersonal competence, communication skills, cultural awareness and a sense of identity (Schuetz, 2008). These elements all comprise emotional intelligence and social skill development. It is crucial that colleges and higher education institutions place emphasis on emotional development and not only cognitive development. Success after graduation for students is dependent upon their ability to maintain healthy interactions, regulate emotions and possess cognitive and intellectual abilities. There is the significant need for the creation and implementation of programmes which enhance the cognitive and non-cognitive skills of undergraduate students (Terenzini et al., 1996). Through the use of EI instruments and assessments, teachers and curriculum developers can identify the EI of students and spot areas that need 
to be improved upon. The experiences of students both outside and inside the classroom are also beneficial in developing their EI.

\section{RESEARCH METHODOLOGY}

This paper conducted case study research that sought to assess the EI of fourth year undergraduate students studying construction related courses at Kwame Nkrumah University of Science and Technology, Kumasi, Ghana. Although the case study is limited to a single higher education institution, future work will be proposed to address this potential limitation. Fourth year students were chosen as it was felt that having studied extensively within the University that their level of EI would be at a mature (and preemployment) state. A number of EI instruments are available for assessing the level of EI. According to Mo and Dainty (2007), these instruments differ in their method of assessment and by their content. Four of these instruments are the most popular, namely: The Emotional Competence Inventory (ECI) 360; the Schutte Self-Report Inventory (SRRI); the Mayer-Saloyey-Caruso Emotional Intelligence Test (MSCEIT); and the BarOn Emotional Quotient Inventory (EQ-i). For this research the EI questionnaire (EQ-i) provided the data collection instrument that was distributed among the undergraduate built environment students.

\section{BarOn Emotional Quotient Inventory (EQ-i)}

According to BarOn (2006), EI is defined as the social and emotional skills which have an influence on how we express and understand ourselves. It also involves how students interact and understand others including everyday behaviours. BarOn (ibid) worked on the BarOn Emotional Quotient Inventory (EQ-i) for about seventeen years and validated this work to serve as an assessment of EI. The EQ-I is made up of five major components 
(namely: i) interpersonal component; ii) intrapersonal component; iii) adaptability; iv) stress management; and v) general mood) and fifteen subscales. The interpersonal component relates to interpersonal interactions $\left(i_{1}\right)$ and social awareness $\left(i_{2}\right)$. It has three subscales. Empathy refers to the capability to have an awareness and understanding about the feeling of others. Social responsibility is the capability to be constructive, cooperative and to be a responsible member of the community. Interpersonal relationships refer to the ability to pleasantly relate to others and have healthy interactions with them (Nasir and Masrur; 2010). The intrapersonal component relates to self-expression and self-awareness. It has five subscales. Emotional self awareness (ii ${ }_{1}$ ) encompasses understanding and having awareness of one's emotions. Self regard (ii 2 ) comprises having respect, acceptance and understanding for oneself. Self actualization (ii 3 ) is the capability to reach out and achieve one's potentials. Assertiveness (ii4) is the ability to efficiently defend, express and stand for one's thoughts and beliefs. Independence (ii 5 ) is the capability of having selfcontrol and self direction (BarOn, 2006). The adaptability component relates to the capability to cope and adjust with change and its resultant problems. It has three subscales. Reality testing (iii ${ }_{1}$ ) is the ability to judge objectively internal feelings and external realities. Flexibility (iii 2 ) is the capability to adjust one's emotions and thoughts depending on the situation and to also cope in new circumstances. Problem solving (iii 3 ) is the aptitude of identifying problems and proposing lasting solutions (Nasir and Masrur; 2010). The stress management component comprises regulating and managing emotions. It has two subscales. Stress tolerance (iv 1 ) is the capability to endure the most unpleasant and difficult circumstances by effectively managing emotions. Impulse control (iv 2 ) is the ability to delay or resist a temptation, desire or drive by withholding one's emotions (BarOn, 2006). The general mood component of the emotional intelligence model involves competencies which relate to self-motivation. It has two subscales. Happiness $\left(\mathrm{v}_{1}\right)$ is the 
ability to enjoy life, exhibit positive feelings and have satisfaction with life. Optimism $\left(\mathrm{v}_{2}\right)$ is the capability to be positive, have a bright outlook on life and stay hopeful in spite of negativities and difficulties (Nasir and Masrur; 2010). These components and subscales were ranked on a 5-point Likert item scale where: $1=$ not true of me; $2=$ seldom true of me; $3=$ sometimes true of me; $4=$ often true of me; and $5=$ very true of me.

\section{Sample Size and Composition}

Two hundred (200) fourth year built environment students in four construction related programmes were randomly selected using pseudo random numbers. A total of 182 questionnaires were completed and retrieved from the fourth-year students thus representing a high $91 \%$ response rate. This high rate of response was achieved due to colleagues to persistently requested that students complete the questionnaire and so contribute to this important study. This sample comprised of 42 students from BSc. Architecture (Arch); 33 students from BSc. Civil Engineering (CE); 52 students from BSc. Construction Technology and Management (CTM) and 55 students from Quantity Surveying and Construction Economics (QSCE). On average (arithmetic mean), it took averagely 25 minutes for students to finish filling in the questionnaire.

\section{Research Ethics and Data Handling}

Given the potentially personally sensitive nature of data collected, a strict two stage ethical process was adopted. During the first stage, the lead researcher sought ethical approval from the host institution (KNUST, Ghana) before commencing any research. This involved completing an ethical pro-forma checklist approved by the college's research ethics committee. During the second stage (and prior to completing the questionnaires), any ethical conditions and constraints were formally agreed between members of the research 
team, namely that: the process was fully supervised by a member of KNUST research team at all times; and information about the research would be made freely available to all participating students post publication of the findings. In addition, all students were assured of strict anonymity and confidentiality and that they had the right to withdraw from the process at any stage. Quotes and any other comments made would not be attributed to any of the respondents by name. All data collected was kept in a safe place (held on the university's network and password protected file storage drive). Finally, prior to commencing the research, the participant's permission was requested to participate in the research and reassurance given that the recording would not be disclosed, divulged or misused (deliberately or otherwise) in any way or form. A preamble of EI and the aim of the research was then provided to the students before they filled the questionnaires. Incomplete or invalidly filled questionnaires were not added to the sample for analysis. The questionnaire had respondent profile questions and a number of variables of EQ-i. Analytical tools included descriptive statistics, mean score ranking, regression and correlation.

\section{FINDINGS AND DISCUSSION}

Before detailed analysis was undertaken, Cronbach's alpha was conducted for testing internal consistency of the data. According to Norusis (2005), the Cronbach's Alpha Reliability must exceed 0.70 . From Table 1 below, the alpha reliability coefficient of EQ-i was 0.90 . The sub-scales had coefficients ranging from 0.72 to 0.89 . These results imply a high internal consistency of the data collection instrument.

<Insert Table 1 about here> 
The demography of respondents is reported below in Table 2. Assessing the profile of the respondents provides invaluable background information on them and adds credence to the responses and concomitant research findings. On the programme of the respondents, 42 students (representing 23.1 percent) were Architecture students; 33 students (representing 18.1 percent) were Civil Engineering students; 52 students (representing 28.6 percent) were Construction Technology Management students; and 55 students (representing 30.2 percent) were Quantity Surveying and Construction Economics students. The implication of this distribution within the sample is that this study had an adequate representation of built environment student professions which is good for inference purposes. Regarding the gender of the students, 26 respondents (representing 14.3 percent) were females while the remaining 156 respondents (representing 85.7 percent) were males which again mirrors contemporary built environment employment practices where the sector is dominated by males. The fourth-year students were also asked their age. 62 respondents (representing 34.1 percent) are 19-22 years; 96 respondents (representing 52.7 percent) are 23-26 years; and the remaining 24 respondents (representing 13.2 percent) are 27 years and above.

$<$ Insert Table 2 about here>

Tables 3 shows the descriptive statistics (average EI scores) for the four programmes. CTM students had the highest EI with a value of 160; CE students were second with value of 156; QSCE students were placed third with value of 140; and Arch students had the least EI value of 134. A likely explanation of the rankings may be attributed to the nature of the taught modules for these programmes. For example, in a study by Chinowsky and Brown (2004), civil engineering students in the United States lagged behind in EI when compared to the comparison sample. However, in this study they were placed second. By 
comparing the EI scores in this research with past studies, it provides a relative basis for assessing the EI of built environment students. In the majority of past research undertaken, female students were seen to have higher EI scores as compared to their male counterparts; this would concur with past research that suggests that women are better than men when dealing with some forms of empathy (Hojat et al., 2002). At present, women are underrepresented within the industry and hence, this later finding suggests that a more concerted effort is required to recruit female colleagues to bolster levels of EI within a PMT.

\section{<Insert Table 3 about here>}

To carry out further analysis on whether there existed statistically significant correlation among EI and the built environment programmes, Pearson Correlation coefficients were calculated - where the programmes were the dependent variable. From the findings in Table 4 below, there is insignificant or low correlation between the built environment programmes and EI level of the students. The results show that the EI level of the students is not statistically dependent on the programmes undertaken by the students; such illustrates a notable dearth of student coaching and mentoring for EI development within current curriculum provisions. However, there should be concerted efforts in increasing the EI levels of these students especially as they are in the fourth year and will be graduating soon to face the working environment. Construction education worldwide currently faces many challenges in training their students in EI (Mo and Dainty, 2007). The traditional approach to educating built environment graduates therefore requires modification, not necessarily in terms of curriculum content but rather in the approach to mentoring and coaching future generations of professionals. Such would include encouraging: active listening to create genuine two-way communication between staff and students; such is a 
prerequisite skill and competency within any PMT (Bodie, 2015); the development of emotional vocabulary to explore and comprehend the differences between emotions felt (Kashdan et al., 2015); the development of self-awareness to understand how a student's self-image can impact upon their behaviour and social interaction within a PMT (Grossman and van der Weele, 2017); and enhance abilities to self-manage emotions and feelings via self-regulation (Smit et al., 2017).

$<$ Insert Table 4 about here>

Calculations were computed for the students' mean scores on total EQ-i and the five composite scales. The mean values, standard deviation, standard error means as well as their t-values were computed (refer to Table 5). There was no significant difference in the overall EQ-i scores of the fourth-year students.

\section{$<$ Insert Table 5 about here>}

Regression analysis was conducted to analyse if students' age was a significant predictor of EI. From Table 6 below, the coefficient of correlation (R) between age and emotional intelligence was 0.33 and $\mathrm{R}^{2}$ was 0.14 . This result shows that age is a significant predictor of emotional intelligence $(\mathrm{F}=15.54, \mathrm{p}<0.05)$ and it accounted for 14 percent variance in the students' ages $\left(\mathrm{R}^{2}=0.14\right)$. This finding corroborates research undertaken by BarOn (2006) and Fariselli et al. (2006) that age brings about more emotional intelligence and social attributes. However, the findings do not agree with past studies by Nasir and Masrur (2010); Balci-Celik and Deniz (2008); and Harrod and Scheer (2005). It is anticipated that the antithesis and thesis presented in these aforementioned studies will continue to 
generate unabated academic discourse. In any event, further multivariate analysis is required to: i) identify other significant variables that could cumulatively predict EI; and ii) using these variables, develop a more robust predictive model with a much higher $\mathrm{R}^{2}$ value.

$<$ Insert Table 6 about here>

\section{CONCLUSION AND RECOMMENDATIONS}

In descending order, CTM students had the highest EI value followed by CE students, QSCE students and lastly Arch students. There was no significant difference in the overall EQ-i scores of the fourth-year students. Furthermore, there is insignificant correlation between the built environment programmes and EI level of the students. The results reveal that the EI level of the students is not statistically dependent on the programmes undertaken by the students. Age was also seen to be a significant predictor of emotional intelligence. From the research findings, it is evident that non-cognitive characteristics must be given priority in the educational sector. Students should not only be prepared for academic work but social settings too. EI is crucial in creating positive interpersonal relationships among students and their teachers and also between their peers. EI helps to contain the effects of negative emotions and increases positive emotions. When university students develop their EI, it leads to overall personal development, better academic performance and success at the workplace after graduation. Since it is expected of university students to graduate and then enter the working world, EI will develop useful skills related to management, leadership and teamwork. When the curricula of students concentrate on positive interactions, healthy emotional development and an enriching/ brighter outlook for a great life will create help students to acquire personal traits/ 
characteristics such as optimism, empathy and understanding. Such will ensure that they will endure tough situations and use them as a springboard for future success.

The study's findings will be useful in assessing the EI level of students albeit, admittedly, future work is required. Such future work will include: i) extending the research to other higher education institutes, in developing countries that have built environment programmes. Such work will facilitate a comparative analysis between various cohorts of students but also create a larger sample size and greater opportunities to draw inference fort the entire population; ii) conducting a more in-depth 'follow-on study' that will seek to develop accurate multivariate deterministic models (perhaps using parametric multiple regression) to better predict the EI of students. This work should aspire to measure how EI develops through the curriculum and importantly, identify how such could be improved upon prior to seeking employment within the construction sector; and iii) from a pedagogical perspective, immerse built environment students within curricular content that specifically acknowledges the inherent value of management and leadership skills. This will result in a paradigm shift in position away from the pure (and historical) pursuit of technical skills and abilities. 


\section{REFERENCES}

Abdullah, M.C., Elias, H., Mahyuddin, R. and Uli, J. (2004) Emotional Intelligence and Academic Achievement Among Malaysian Secondary Students, Pakistan Journal of Psychological Research, Vol. 19, No. 34, pp. 105-121.

ABET (Accreditation Board for Engineering and Technology) (2005) Criteria for Accrediting Engineering Programmes. Available via: www.abet.org (Accessed: January, 2018).

Al-Rabadi, W. M. (2012) Emotional Intelligence and its Relation with Ajloun University College Students Psychological Harmony, European Journal of Social Sciences, Vol. 34, pp. 284-299.

Andi, H. K. (2012) Relationships Between Emotional Intelligence and 'The Big Five In Youths, Malaysian Journal of Youth Studies, Vol. 7, pp. 125-135.

Balci-Celik, S and Deniz, M. E. (2008) A Comparison of Scouts' Emotional Intelligence Levels with Regards to Age and Gender Variables: A Cross-cultural Study. Elementary Education Online, Vol. 7, No. 2, pp. 376-383.

BarOn, R. (1997) Emotional Intelligence in Men and Women, BarOn Emotional Quotient Inventory: Technical Manual, Toronto: Multi-Health System.

BarOn, R. (2006) The Bar-On Model of Emotional-Social Intelligence (ESI), Psicothema, Vol. 18, pp. 13-25.

Barsade, S. G. (2002) The Ripple Effect: Emotional Contagion and its Influence on Group Behaviour, Administrative Science Quarterly, Vol. 47, pp. 644-675.

Bodie, G. D., Vickery, A. J., Cannava, K. and Jones, S.M. (2015) The Role of Active Listening in Informal Helping Conversations: Impact on Perceptions of Listener Helpfulness, Sensitivity, and Supportiveness and Discloser Emotional Improvement, Western Journal of Communication, Vol. 79, No. 2, pp. 151-173. 
Carmeli, A. (2003) The Relationship Between Emotional Intelligence and Work Attitudes, Behaviour and Outcomes: An Examination Among Senior Managers, Managerial Psychology, Vol. 18 No. 8, pp. 788-813.

Chinowsky, P. S. and Brown, H. (2004) The Development of Successful Intelligence in Construction Education, Proceedings of the 20th Annual Conference of the Association of Researchers in Construction Management, Vol. 1, pp. 525-532

Crossman, J. (2007) The Role of Relationships and Emotions in Students' Perceptions of Learning and Assessment, Higher Education Research \& Development, Vol. 26, No. 3, pp. 313-327.

Das, A. (2011) Effects of Personality on Emotion Intelligence Between Professional and Nonprofessional Students: Some Exploratory Evidence, Asia Journal of Management Research, Vol. 1, No. 2, pp. 746-758,

Debarard, M., Spelmans, G. and Julka, D. (2004) Predictors of Academic Achievement and Retention Among Freshmen: A Longitudinal Study. College Student Journal, Vol. 38, No. 1, pp. 66-80.

Edwards, D. J. and Love, P. E. D. (2016) A Case Study of Machinery Maintenance Protocols and Procedures within the UK Utilities Sector. Accident Analysis and Prevention, 93, pp. 319-329.

Edwards, D.J., Pärn, E.A., Love, P.E.D. and El-Gohary, H. (2016) Machines, Manumission and Economic Machinations, Journal of Business Research, Vol. 70 pp. 391-394.

Elias, M. J. (2004) The Connection Between Social-emotional Learning and Learning Disabilities: Implications for Intervention. Learning Disability Quarterly, Vol. 27, pp. 53-63 
Fariselli, L., Ghini, M. and Freedman, J. (2006) Emotional Intelligence and Age, Available via: http://www.6seconds.org/sei/ wp-age.php (Accessed: January 2017).

Feldmann, M., Aper, J. P. and Meredith, S. T. (2011) Co-curricular Assessment Scale Development, The Journal of General Education, Vol. 60, No. 1, pp. 16-42.

Fredrickson, B. L. (2003) Positive Emotions and Upward Spirals in Organizations. In: Cameron, K. S. Dutton, J. E. and Quinn, R. E. (Eds), Positive Organisational Scholarship: Foundations of a New Discipline. Barrett Koehler, San Francisco.

Gardner, H. (1983) Frames of Mind: The Theory of Multiple Intelligences. Basic Books, New York.

Goleman, D. (1995) Emotional Intelligence. New York: Bantam Books

Grossman, Z. and van der Weele, J. J. (2017) Self-Image and Willful Ignorance in Social Decisions, Journal of the European Economic Association, Vol. 15, No. 1, pp. $173-217$.

Harrod, N. R. and Scheer, S.D. (2005). An Explanation of Adolescent Emotional Intelligence in Relation to Demographic Characteristics. Adolescence, Vol. 40, No.159, pp. 503-512.

Hojat, M., Gonnella, J. S., Nasca, T. J., Mangione, S., Vergare, M. and Magee, M. (2002) Physician Empathy: Definition, Components, Measurement, and Relationship to Gender and Specialty, The American Journal of Psychiatry, Vol. 159, No. 9, pp. 1563-1569.

Iruloh B. R. N. and Ukaegbu, H. M. (2015) Big Five Personality Traits as Predictors of Emotional Intelligence of Secondary School Teachers in Rivers State of Nigeria, European Journal of Psychological Research, Vol. 2, No. 2, pp. 52-59. 
Jagger N. and Connor S. (1998) Employers' and Recent Postgraduates' Views of the Personal Skills Requirement of Engineering Postgraduates, Civil and Structural Engineering Education in the 21st Century, Vol. 2, pp. 423-434.

Kashdan, T.B., Barrett, L.F. and McKnight, P.E. (2015) Unpacking Emotion Differentiation: Transforming Unpleasant Experience by Perceiving Distinctions in Negativity, Current Directions in Psychological Science, Vol. 24, No. 1, pp. 10-16.

Kemper, C. L. (1999) EQ vs. IQ, Communication World, Vol. 16, pp.15-22

Mayer, J. D. and Salovey, P. (1990) Emotional Intelligence. Imagination, Cognition and Personality, Vol. 9, No. 3, pp. 185-211

Mayer, J.D., and Salovey, P (2004) What is Emotional Intelligence? In P. Salovey, M.A. Brackett, and J.D. Mayer (Eds.), Emotional Intelligence: Key Readings on the Mayer and Salovey model (pp. 29-59). Port Chester, NY: Dude Publishing.

Mo, Y. and Dainty, A.R.J. (2007) Measuring and Enhancing the Emotional Intelligence of Construction Management Students: An Empirical Study, Journal for Education in the Built Environment Vol. 2, No. 1, pp. 110-119

Nasir M. and Masrur, R. (2010) An Exploration of Emotional Intelligence of the Students of IIUI in Relation to Gender, Age and Academic Achievement. Bulletin of Education and Research, Vol. 32, No. 1, pp. 37-51

Norusis, M. (2005) The SPSS Guide to Data Analysis for SPSS-X, SPSS Inc., Chicago.

Parker, J.D.A, Creque, R.E., Barnhart, D.L., Majeski, S.A, Hogan, M.A., Wood, L.M., Bond, B.J. and Harris, J.I. (2004) Achievement in High School: Does Emotional Intelligence Matter? Personality and Individual Differences, Vol. 38, pp. 13211330.

Parker, J. D., Duffy, J. M., Wood, L. M., Bond, B. J., and Hogan, M. J. (2005) Academic Achievement and Emotional Intelligence: Predicting the Successful Transition 
from High School to University, Journal of the First-Year Experience \& Students in Transition, Vol. 7, No. 1, pp. 67-78.

Pärn, E.A. and Edwards, D.J. (2017) Conceptualizing the FINDD Toolkit: A Case Study of BIM/ FM Integration, Automation in Construction, Vol. 80, pp. 11-21.

Pärn, E. A., Edwards, D. J. and Sing, M. C. P. (2018) Origins and Probabilities of MEP and Structural Design Clashes within a Federated BIM model. Automation in Construction, 85, pp. 209-219.

Petrides, K. V., and Furnham, A. (2000) On the Dimensional Structure of Emotional Intelligence, Personality and Individual Differences, Vol. 29, pp. 313-320.

Sandy, L., Frederick C., Lunenburg J. and Slate, R. (2012) Emotional Intelligence and Academic Success: A Conceptual Analysis for Educational Leaders, International Journal of Educational Leadership Preparation, Vol. 7, No. 1, pp. 22-29

Schuetz, P. (2008) A Theory-Driven Model of Community College Student Engagement. Community College Journal of Research and Practice, Vol. 32, No. 4-6, pp. 305324.

Schutte, N. S. and Malouff, J. M. (2002) Incorporating Emotional Skills Content in a College Transition Course Enhances Student Retention, Journal of the First-Year Experience, Vol. 14, No. 1, pp. 7-21

Schutte, N. S., Malouff, J. M., Hall, L. E., Haggerty, D. J., Cooper, J.T., Golden, C. J. and Dornheim, L. (1998) Development and Validation of a Measure of Emotional Intelligence, Personality and Individual Differences, Vol. 25, pp. 167-177.

Seal, C. R., Naumann, S. E., Scott, A. N. and Royce-Davis, J. (2010) Social Emotional Development: A New Model of Student Learning in Higher Education, Research in Higher Education Journal, Vol. 10, pp. 1-13. 
Smit, K., de Brabandera, C.J., Boekaerts, M. and Martens, R.L. (2017) The Self-regulation of Motivation: Motivational Strategies as Mediator Between Motivational Beliefs and Engagement for Learning, International Journal of Educational Research, Vol. 82, pp. 124-134.

Sy, T., Cote, S. and Saavedra, R. (2005) The Contagious Leader: Impact of the Leader's Mood on the Mood of Group Members, Group Affective Tone, and Group Processes, Applied Psychology, Vol. 90, pp. 295-305.

Tabish, S.Z.S. and Jha, K.N. (2012) Success Traits for A Construction Project. Journal of Construction Engineering and Management, Vol. 138, No. 1, pp. 1131-1138.

Terenzini, P. T., Pascarella, E. T. and Blimling, G. S. (1996) Students' Out-of-class Experiences and their Influence on Learning and Cognitive Development: A Literature Review. Journal of College Student Development, Vol. 37, No. 2, pp. 149-162.

Thorndike, E. L. (1920) Intelligence and its Use. Harper's magazine, Vol. 140, pp. $227-$ 235.

Zembylas, M. (2017) Wilful Ignorance and the Emotional Regime of Schools, British Journal of Educational Studies, Vol. 64, No. 4, pp. 499-515.

Zhou, J. and Georg, J.M. (2003) Awakening Employee Creativity: The Role of Leader Emotional Intelligence, Leadership Quarterly, Vol. 14, pp. 545-568. 
Table 1 - Alpha Reliability Coefficients of EQ-i and Subscales (15)

\begin{tabular}{lll}
\hline & Scale & Alpha Coefficient \\
\hline & EQ-i & 0.90 \\
1 & Emotional Self Awareness & 0.83 \\
2 & Assertiveness & 0.78 \\
3 & Self-Regard & 0.88 \\
4 & Self-Actualization & 0.75 \\
5 & Independence & 0.75 \\
6 & Interpersonal Relationship & 0.77 \\
7 & Social Responsibility & 0.81 \\
8 & Empathy & 0.76 \\
9 & Problem Solving & 0.80 \\
10 & Reality Testing & 0.72 \\
11 & Flexibility & 0.89 \\
12 & Stress Tolerance & 0.78 \\
13 & Impulse Control & 0.77 \\
14 & Happiness & 0.74 \\
15 & Optimism & 0.83 \\
\hline
\end{tabular}


Table 2 - Respondents' Profile

\begin{tabular}{llcc}
\hline & & Frequency & Percentage \\
\hline Programme & Architecture & 42 & 23.1 \\
& Civil Engineering & 33 & 18.1 \\
& Construction Technology Management & & \\
& (CTM) & 52 & 28.6 \\
& Quantity Surveying and Construction & & \\
& Economics (QSCE) & 55 & 30.2 \\
\multirow{5}{*}{ Gender } & Total & 182 & 100.0 \\
& Female & 26 & 14.3 \\
& Male & 156 & 85.7 \\
& Total & 182 & 100.0 \\
& 19-22 years & 62 & 34.1 \\
& 23-26 years & 96 & 52.7 \\
& 27 years and above & 24 & 13.2 \\
& Total & 182 & 100.0 \\
\hline
\end{tabular}


Table 3 - EI Descriptive Statistics Across Programmes

\begin{tabular}{lccc}
\hline & N & Mean & Std. Dev. \\
\hline Architecture (ARC) & 42 & 134 & 14 \\
Civil Engineering (CE) & 33 & 156 & 15 \\
Construction Technology & 52 & 162 & 16 \\
$\begin{array}{l}\text { Management (CTM) } \\
\text { Quantity Surveying and }\end{array}$ & 55 & 140 & 15 \\
Construction Economics (QSCE) & & & \\
\hline
\end{tabular}


Table 4 - Correlations for Different Built Environment Programmes with Total Emotional Intelligence

\begin{tabular}{lccccc}
\hline & ARC & CE & CTM & QSCE & Total \\
\hline Architecture (ARC) & -- & $.214^{* *}$ & -.327 & $-.388^{* *}$ & 0.24 \\
Civil Engineering (CE) & -- & -- & $-.123^{* *}$ & $-.136^{* *}$ & -.046 \\
Construction Technology & -- & -- & -- & $-.299^{* *}$ & -.142 \\
Management (CTM) & & & & & \\
Quantity Surveying and & -- & -- & -- & -- & .178 \\
Construction Economics & & & & & \\
QSCE) & -- & -- & -- & -- & -- \\
Total & -- & & & \\
\hline
\end{tabular}

** Correlation significant at the 0.01 level (2-tailed)

a. Listwise $\mathrm{N}=182$ 
Table 5 - Analysis of Students' Mean Scores on Total EQ-i and 5 Composite Scales

\begin{tabular}{lcccc}
\hline Scales & Mean & $\begin{array}{c}\text { Standard } \\
\text { deviation }\end{array}$ & $\begin{array}{c}\text { Standard } \\
\text { error mean }\end{array}$ & $\begin{array}{c}\text { T- } \\
\text { value }\end{array}$ \\
\hline EQ-i & 592.00 & 60.218 & 6.032 & 0.213 \\
Intrapersonal & 187.20 & 16.05 & 1.213 & 0.534 \\
Interpersonal & 168.00 & 13.13 & 1.095 & 0.148 \\
Adaptability & 108.40 & 11.49 & 0.812 & 0.237 \\
Stress Management & 73.80 & 10.22 & 1.118 & 0.114 \\
General Mood & 54.60 & 9.72 & 0.932 & 0.405 \\
\hline
\end{tabular}

$* p<0.05$ 
Table 6 - Regression Analysis for Age and Emotional Intelligence

\begin{tabular}{lcccc}
\hline & $\begin{array}{c}\text { Coefficient of } \\
\text { correlation }(\mathbf{R})\end{array}$ & F value & $\mathbf{R}^{2}$ & Sig (p) \\
\hline Age & 0.33 & 15.540 & 0.14 & 0.004 \\
\hline
\end{tabular}

